\title{
Studies on the Effect of Nitrogen and Potassium Fertilizers on Growth, Herbage and Oil Yield of Palmarosa in Irrigation Condition (Cymbopogan martini [Roxb.] Will. Watson)
}

\author{
J. Cheena ${ }^{1 *}$, V. Krishna Veni ${ }^{1}$, M. Padma ${ }^{2}$ and M. Sreenivas ${ }^{3}$ \\ ${ }^{1}$ Medicinal and Aromatic Plant Research Station, Rajendranagar, Hyderabad, ${ }^{2}$ Horticulture, \\ Mulugu, Siddipet,Sri Konda Laxman Telangana State Horticultural University, \\ Mulugu (V\& M), Siddipet dist., Telangana, India \\ ${ }^{3}$ College of Horticulture, Mojerla, Wanaparthy, Sri Konda Laxman Telangana State \\ Horticultural University, Mulugu ( $\&$ \& $)$, Siddipet dist., Telangana, India \\ *Corresponding author
}

\section{A B S T R A C T}

\begin{tabular}{|l|}
\hline Ke y w o r d s \\
Palmarosa, \\
Nitrogen, \\
Potassium, \\
Essential oil yield, \\
Herbage \\
\hline Article Info \\
\hline $\begin{array}{l}\text { Accepted: } \\
\text { xx November } 2020 \\
\text { Available Online: } \\
\text { xx December } 2020\end{array}$ \\
\hline
\end{tabular}

An investigation was carried out at Medicinal and Aromatic Plant Research Station Rajendranagar, Sri Konda Laxman Telangana State Horticultural University, Mulugu (V \& M), Siddipet Dist., Telangana State during the period of 2017-20 to determine the effect of Nitrogen and Potassium fertilizers on growth, herbage and oil yield of Palmarosa in irrigation condition. The study was conducted with the application of different levels of Nitrogen i.e, $0 \mathrm{~kg} / \mathrm{ha}, 100 \mathrm{~kg} / \mathrm{ha}, 200 \mathrm{~kg} / \mathrm{ha}$, different levels of potassium $0 \mathrm{~kg} / \mathrm{ha}, 61.5 \mathrm{~kg} / \mathrm{ha}, 123 \mathrm{~kg} / \mathrm{ha}$. The parameters in terms of fresh herbage yield, oil yield were significantly differed with respect to the different dosage of Nitrogen and potassium. The maximum plant height $(198.35 \mathrm{~cm})$, no. of tillers/clump (46.86), fresh herbage yield (44.98 t/ha), essential oil yield $(4.78 \mathrm{ml} / \mathrm{kg})$ were found in $\mathrm{N}_{3} \mathrm{~K}_{3}$ while the minimum plant height, no. of tillers/clump, fresh herbage yield, essential oil yield were found in $\mathrm{N}_{1} \mathrm{~K}_{1}$.

\section{Introduction}

Palmarosa (Cymbopogan martini [Roxb.] Will.Watson) commonly known as Rosha grass. It is a tall perennial tufted hedge which contains a sweet smelling oil of rose like odour. Palmarosa oil also has notes of rye bread, tea and clary sage (Mallavarapu et al., 1998). It is native of most parts of subtropical India and grows in warm humid areas. The oil is extensively used as perfumery raw material in soaps, perfumes, cosmetics preparations and in the manufacture of mosquito repellent products. It is used for flavoring tobacco products, foods and nonalcoholic beverages (Prakasa Rao et al., 1985). The volatile oil is used as a remedy for lumbago, stiff joints, skin diseases and for bilious complaints (Rajeswara Rao, 1999). The oil is a very rich source of high grade 
geraniol (75-90\%) and the crop is regarded as the cheap source of geraniol. Moreover it is a hardy crop which can be grown on varied types of soil and climatic conditions. It can even tolerate drought and could be grown on marginal waste lands including saline/sodic/alkaline soils. Palmarosa grows wild in India, particularly in Madhya Pradesh, Maharashtra, and Andhra Pradesh. It is also found in lesser frequency in Karnataka, Tamilnadu and Uttar Pradesh. India accounts for $70 \%$ of the total annual world production of palmarosa oil (Lawrence 1985) and is a major supplier to the world market. The growth and yield of Palmarosa plantation mainly depend upon the proper selection of variety and its nutritional management.

Nitrogen is most recognized in plants for its presence in the structure of protein molecule. Nitrogen fertilization enhanced the development of the aerial parts. The crop is being cultivated in large area and the application of nitrogen fertilizer was found to increase herbage and oil yields (Prakasa Rao et al., 1985; Yadav et al., 1985; Rajeswara Rao et al., 1991). Potassium is a key essential plant nutrient although it is not a constituent of any plant part. It acts as catalyst for many of the enzymatic processes which are necessary for plant growth. It also regulates the opening and closing of stomata which affect carbon dioxide uptake for photosynthesis (Somida 2002). Potassium uptake is very high by palmarosa under irrigated condition (Prakasa Rao and Ganesha Rao 1996). Lemongrass (C. flexuosus), Tagetes minuta and palmarosa (C. martinii) also responded to $\mathrm{K}$ application (Prakasa Rao et al., 2001; Singh et al., 2005; Singh and Ganesha Rao 2005). Recently, there is evidence that $\mathrm{K}$ may become a limiting factor in the cultivation of some essential oil bearing plants in red soil regions (Prakasa Rao et al., 1996). The present work was therefore undertaken to study the cultivation practices of different nitrogen and potassium fertility levels by Palmarosa crop.

\section{Materials and Methods}

The experiment entitled "Studies on the effect of Nitrogen and Potassium fertilizers on growth, herbage and oil yield of Palmarosa in irrigation condition (Cymbopogan martini [Roxb.] Will.Watson)" was carried out for three years (2017-2020) at Medicinal and Aromatic Plant Research Station Rajendranagar, SKLTSHU, Hyderabad.

The meteorological data were collected from the Agricultural Research Institute, Rajendranagar for the experimental period of three years (2017-2020). It comes under sub tropical zone and is situated at latitude of $17^{0} 30^{1} \mathrm{~N}$ and longitude of $78^{0} 42^{1} \mathrm{E}$. It was normal weather data on total rainfall, maximum and minimum temperature, relative humidity, that prevailed during the period of experimentation.

The land used under the experimental layout was red with good drainage and low water holding capacity with uniform texture. The soil characteristics were, $\mathrm{pH} 7.20$, electrical conductivity $0.67 \mathrm{dSm}-1$, organic carbon $0.32 \%$, Available Nitrogen $120 \mathrm{~kg} / \mathrm{ha}$, Available Phosphorus $48 \mathrm{~kg} / \mathrm{ha}$, Available Potassium $60 \mathrm{~kg} / \mathrm{ha}$.

The experiment was designed in Factorial Randomised Block Design with three replications with the spacing of $45^{*} 30 \mathrm{~cm}$. At the time of planting, fertilizer application of $120 \mathrm{~kg} / \mathrm{ha}$ of Single Super Phosphate was applied. In the experiment, different levels of Nitrogen i.e, $0 \mathrm{~kg} / \mathrm{ha}, 100 \mathrm{~kg} / \mathrm{ha}, 200 \mathrm{~kg} / \mathrm{ha}$, different levels of Potassium 0kg/ha, $61.5 \mathrm{~kg} / \mathrm{ha}, 200 \mathrm{~kg} / \mathrm{ha}$ was applied.

The following agronomic practices of Palmarosa were recorded as follows, 
Plant height (cm): The plant height was recorded before each harvest.

No. of tillers/clump: The number of tillers/clump were recorded 90 days after sowing, in each plot taking 5 plants into consideration.

Fresh herbage yield (t/ha): In each plot, the crop was harvested with sickle $20 \mathrm{~cm}$ above the ground level and immediately weighted for obtaining plot yield. Then plot yield was transferred to yield per hectare. A total of 11 harvests were taken during three years.

Essential oil yield ( $\mathrm{ml} / \mathrm{kg}$ herbage): The essential oil extraction was done at laboratory of Medicinal and Aromatic Plant Research Station, Rajendranagar. Fresh leaves essential oil was estimated using Clevenger's apparatus (Clevenger 1928). The chemical constituents of Palmarosa like geraniol and geranyl acetate were determined by gas chromatography.

\section{Results and Discussion}

\section{Plant height (cm)}

A significant difference was observed on plant height due to application of different dosage of Nitrogen. The maximum plant height $(191.81 \mathrm{~cm})$ was recorded with Nitrogen of $200 \mathrm{~kg} / \mathrm{ha}$ while the minimum plant height $(158.77 \mathrm{~cm})$ was recorded with Nitrogen of $0 \mathrm{~kg} / \mathrm{ha}$.

Plant height was not found significant due to application of different dosage of potassium. The maximum plant height $(180.98 \mathrm{~cm})$ was recorded with Potassium of $123 \mathrm{~kg} / \mathrm{ha}$ while the minimum plant height $(166.62 \mathrm{~cm})$ was recorded with Potassium of $0 \mathrm{~kg} / \mathrm{ha}$.

The interaction effect of Nitrogen and Potassium showed significant variation on plant height (Table 1). The highest plant height $(198.35 \mathrm{~cm})$ was recorded with Nitrogen of $200 \mathrm{~kg} / \mathrm{ha}$ and Potassium of $123 \mathrm{~kg} / \mathrm{ha}\left(\mathrm{N}_{3} \mathrm{~K}_{3}\right)$ which was on par $(194.75 \mathrm{~cm})$ with Nitrogen of $200 \mathrm{~kg} / \mathrm{ha}$ and Potassium of $61.5 \mathrm{~kg} / \mathrm{ha}\left(\mathrm{N}_{3} \mathrm{~K}_{2}\right)$ while the minimum plant height $(149.25 \mathrm{~cm})$ was obtained with the application of Nitrogen of 0 $\mathrm{kg} / \mathrm{ha}$ and Potassium of $0 \mathrm{~kg} / \mathrm{ha}\left(\mathrm{N}_{1} \mathrm{~K}_{1}\right)$. The $\mathrm{N}$ application increased the biomass and essential oil yields through increased plant height. These results agree with the finding of Singh and Sharma (2001).

\section{No. of tillers/clump}

A significant difference was observed on number of tillers/clump due to application of different dosage of Nitrogen. The maximum number of tillers/clump (45.47) was recorded with Nitrogen of $200 \mathrm{~kg} / \mathrm{ha}$ and the minimum number of tillers/clump (33.15) was recorded with Nitrogen of $0 \mathrm{~kg} / \mathrm{ha}$. Number of tillers/clump was not found significant due to application of different dosage of potassium. The maximum number of tillers/clump (41.67) was recorded with Potassium of $123 \mathrm{~kg} / \mathrm{ha}$ while the minimum number of tillers/clump (37.04) was recorded with Potassium of $0 \mathrm{~kg} / \mathrm{ha}$.

The interaction effect of Nitrogen and Potassium showed significant variation on number of tillers/clump (Table 1). The highest number of tillers/clump (46.86) was recorded with Nitrogen of $200 \mathrm{~kg} / \mathrm{ha}$ and Potassium of $123 \mathrm{~kg} / \mathrm{ha}\left(\mathrm{N}_{3} \mathrm{~K}_{3}\right)$ while the minimum number of tillers/clump (31.25) was obtained from Nitrogen of $0 \mathrm{~kg} / \mathrm{ha}$ and Potassium of $0 \mathrm{~kg} / \mathrm{ha}$ $\left(\mathrm{N}_{1} \mathrm{~K}_{1}\right)$. It was observed that plant height and tiller production at each cutting was highest.

\section{Fresh herbage yield (t/ha)}

A significant difference was observed on fresh herbage yield due to application of different dosage of Nitrogen. The maximum 
fresh herbage yield (42.76 t/ha) was received with Nitrogen of $200 \mathrm{~kg} / \mathrm{ha}$ while the minimum fresh herbage yield $(28.01 \mathrm{t} / \mathrm{ha})$ was received with Nitrogen of $0 \mathrm{~kg} / \mathrm{ha}$. Fresh herbage yield was found significant due to application of different dosage of potassium.
The maximum fresh herbage yield (39.35 t/ha) was received with Potassium of $123 \mathrm{~kg} / \mathrm{ha}$ while the minimum fresh herbage yield (33.03 t/ha) was recorded with Potassium of $0 \mathrm{~kg} / \mathrm{ha}$.

Table.1 Studies on the effect of Nitrogen and Potassium fertilizers on growth, herbage and oil yield of Palmarosa in irrigation condition during 2017-2020

\begin{tabular}{|c|c|c|c|c|c|c|c|c|c|c|c|c|}
\hline \multicolumn{4}{|c|}{ Plant height } & \multicolumn{4}{c|}{ No. of tillers/clump } & \multicolumn{3}{c|}{$\begin{array}{c}\text { Fresh herbage yield/ } \\
\text { clump (kg) }\end{array}$} \\
\hline & K1 & K2 & K3 & Mean & K1 & K2 & K3 & Mean & K1 & K2 & K3 & Mean \\
\hline N1 & 149.25 & 160.76 & 166.32 & 158.77 & 31.25 & 33.65 & 34.56 & 33.15 & 0.86 & 0.98 & 1.17 & 1.00 \\
\hline N2 & 168.29 & 175.46 & 178.29 & 174.01 & 35.29 & 43.58 & 43.59 & 40.82 & 1.2 & 1.36 & 1.45 & 1.33 \\
\hline N3 & 182.34 & 194.75 & 198.35 & 191.81 & 44.59 & 44.96 & 46.86 & 45.47 & 1.49 & 1.5 & 1.61 & 1.53 \\
\hline Mean & 166.62 & 176.99 & 180.98 & & 37.04 & 40.73 & 41.67 & & 1.18 & 1.28 & 1.41 & \\
\hline Factors & SE(M)+- & C.D at 5\% & SE(M)+- & C.D at 5\% & SE(M)+- & C.D at 5\% \\
\hline N & 5.2 & 10.2 & 2.1 & 4.2 & 0.12 & 0.25 \\
\hline K & 4.2 & NS & 1.2 & NS & 1.8 & NS \\
\hline N*K & 3.8 & 8.3 & 1.3 & 3.3 & 0.19 & 0.31 \\
\hline
\end{tabular}

Table.2 Studies on the effect of Nitrogen and Potassium fertilizers on growth, herbage and oil yield of Palmarosa in irrigation condition during 2017-2020

\begin{tabular}{|c|c|c|c|c|c|c|c|c|c|c|c|c|}
\hline \multicolumn{9}{|c|}{ Fresh Herbage Yield/ha (t/ha) } & \multicolumn{3}{c|}{$\begin{array}{c}\text { Essential oil yield/kg } \\
\text { (m1/kg herbage) }\end{array}$} & \multicolumn{3}{c|}{ Essential oil yield/ha (kg/ha) } \\
\hline & K1 & K2 & K3 & Mean & K1 & K2 & K3 & Mean & K1 & K2 & K3 & Mean \\
\hline N1 & 24.08 & 27.28 & 32.69 & 28.01 & 4.48 & 4.5 & 4.53 & 4.50 & 107.87 & 122.76 & 148.08 & 126.23 \\
\hline N2 & 33.57 & 37.89 & 40.39 & 37.28 & 4.58 & 4.61 & 4.62 & 4.60 & 153.75 & 174.67 & 186.6 & 171.67 \\
\hline N3 & 41.46 & 41.85 & 44.98 & 42.76 & 4.68 & 4.72 & 4.78 & 4.72 & 194.03 & 197.53 & 215 & 202.18 \\
\hline Mean & 33.03 & 35.67 & 39.35 & 4.58 & 4.61 & 4.64 & & 151.88 & 164.98 & 183.22 & \\
\hline Factors & SE(M)+- & C.D at 5\% & SE(M)+- & C.D at 5\% & SE(M)+- & C.D at 5\% \\
\hline N & 1.42 & 3.4 & 0.01 & 0.02 & 10.5 & 20.9 \\
\hline K & 3.2 & 4.68 & 0.01 & 0.02 & 8.2 & 17.3 \\
\hline N*K & 2.10 & 3.15 & 0.2 & 0.5 & 8.9 & 18.4 \\
\hline
\end{tabular}

Factor I : Levels of Nitrogen N1- 0 kg/ha., N2- 100 kg/ha., N3- 200 kg/ha.

Factor II : Levels of Potassium K1- 0 kg/ha., K2- 61.5 kg/ha., K3- 123 kg/ha

The interaction effect of Nitrogen and Potassium showed significant variation on fresh herbage yield (Table 2). The highest fresh herbage yield (44.98t/ha) was recorded with Nitrogen of $200 \mathrm{~kg} / \mathrm{ha}$ and Potassium of $123 \mathrm{~kg} / \mathrm{ha}\left(\mathrm{N}_{3} \mathrm{~K}_{3}\right)$ while the minimum fresh herbage yield (24.08t/ha) was obtained from Nitrogen of $0 \mathrm{~kg} / \mathrm{ha}$ and Potassium of $0 \mathrm{~kg} / \mathrm{ha}$ $\left(\mathrm{N}_{1} \mathrm{~K}_{1}\right)$.

According to B.R.Rajeswara Rao (2001), addition of nitrogen $(\mathrm{N})$ at $80 \mathrm{~kg} / \mathrm{ha}$ per year 
enhanced the total biomass yield by $57.6 \%$ and total essential oil yield by $60.3 \%$ in comparison to no $\mathrm{N}$ application. From series of an experiment conducted on lemon grass for more than a decade by Nair et al., (1979) suggested that application of $100 \mathrm{~kg} \mathrm{~N}$ ha-1 was found to be beneficial than control. These results also supported by Sundaravadivel et al., (2000) who reported that the application of $75 \mathrm{Kg} \mathrm{N}$ ha-1 produced highest levels of available nutrients (,,$P$ and $\mathrm{K}$ ) in the soil. Prakasha Rao et al., (1985) observed that application of $\mathrm{N}$ fertilizers $100 \mathrm{~kg} \mathrm{~N}$ ha-1 yr-1 increased the herbage and essential oil yield of $\mathrm{C}$. flexuosus while $\mathrm{P}$ and $\mathrm{K}$ fertilizers did not show any increase. Munnu singh (2008) reported that addition of potassium at $123 \mathrm{~kg}$ ha-1 year-1 gave the maximum total herbage yield of Palmarosa plants compared with zero level.

\section{Essential oil yield (ml/kg herbage)}

A significant difference was observed on oil yield due to application of different dosage of Nitrogen. The maximum oil yield (4.72 $\mathrm{ml} / \mathrm{kg}$ ) was recorded with Nitrogen of 200 $\mathrm{kg} / \mathrm{ha}$ while the minimum oil yield (4.50 $\mathrm{ml} / \mathrm{kg}$ ) was recorded with Nitrogen of 0 $\mathrm{kg} / \mathrm{ha}$. Essential oil yield was found significant due to application of different dosage of potassium. The maximum oil yield $(4.64 \mathrm{ml} / \mathrm{kg})$ was recorded with Potassium of $123 \mathrm{~kg} / \mathrm{ha}$ while the minimum oil yield (4.58 $\mathrm{ml} / \mathrm{kg}$ ) was recorded with Potassium of 0 $\mathrm{kg} / \mathrm{ha}$.

The interaction effect of Nitrogen and Potassium showed significant variation on essential oil yield (Table 2). The highest oil yield $(4.78 \mathrm{ml} / \mathrm{kg})$ was recorded with Nitrogen of $200 \mathrm{~kg} / \mathrm{ha}$ and Potassium of 123 $\mathrm{kg} / \mathrm{ha}\left(\mathrm{N}_{3} \mathrm{~K}_{3}\right)$ which was on par $(4.72 \mathrm{ml} / \mathrm{kg})$ with Nitrogen of $200 \mathrm{~kg} / \mathrm{ha}$ and Potassium of $61.5 \mathrm{~kg} / \mathrm{ha}\left(\mathrm{N}_{3} \mathrm{~K}_{2}\right)$ while the minimum oil yield $(4.48 \mathrm{ml} / \mathrm{kg})$ was obtained from
Nitrogen of $0 \mathrm{~kg} / \mathrm{ha}$ and Potassium of $0 \mathrm{~kg} / \mathrm{ha}$ $\left(\mathrm{N}_{1} \mathrm{~K}_{1}\right)$.

Application of nitrogen at $200 \mathrm{~kg}$ ha-1 year-1 increased total essential oil yield of Palmarosa (Cymbopogon martini) by $102.6 \%$ over control (no added $\mathrm{N}$ ) under semi-arid tropical climate (Munnu singh, 2008). Yadav et al., (1984) studied the fertilizer nitrogen recovery and growth of Java citronella as influenced by nitrogen and concluded that the herbage, citronella oil yields and nitrogen uptake by the crop increased with the increased rate of nitrogen from 0 to $180 \mathrm{~kg}$ ha- 1 in all cuttings. Total herbage production increased by 28.40 and $53 \%$ and Citronella oil by 26, 38 and 49 to due 60,120 and $\mathrm{kg} \mathrm{N}$ ha-1 respectively over control. Prakasha Rao et al., (1983) conducted a two year experiment (1979-81) to study the effect of $\mathrm{N}, \mathrm{P}$ and $\mathrm{K}$ fertilizers on growth and yield of Java citronella in a sandy loam soil. Application of $200 \mathrm{~kg} \mathrm{~N}$ ha-1 yr-1 resulted in significantly high yields of herb and essential oil and uptake of N, P and K.

In conclusion from this investigation, the highest fresh herbage and oil yield was recorded in the treatment combination of Nitrogen of $200 \mathrm{~kg} / \mathrm{ha}$ and Potassium of 123 $\mathrm{kg} / \mathrm{ha}\left(\mathrm{N}_{3} \mathrm{~K}_{3}\right)$. It can be concluded that the herbage yield, oil yields of nitrogen uptake by the crop increased with the increased rate of nitrogen from 0 to $200 \mathrm{~kg} \mathrm{ha}^{-1}$.

\section{References}

Clevenger JF. 1928. Apparatus for the determination of volatile oil. $\mathrm{J}$ Am Pharmaceut Assoc.17:346-348.

Lawrence BM. 1985. A review of the world production of essential oils. Perf Flavor.10:1-16.

Mallavarapu, G.R., Rajeswara Rao, B.R., Kaul, P.N., Ramesh, S. and Bhattacharya, A.K., 1998. Volatile constituents of the essential oils of the 
seeds and herb of palmarosa (Cymbopogon martinii (Roxb.) Wats. var. motia Burk.). Flavour Fragrance J. 13: $167-169$.

Munnu Singh, 2008. Effect of nitrogen and potassium fertilizer on growth, herbage and oil yield of irrigated palmarosa (Cymbopogon martinii [roxb.] wats. var. motia burk) in a semi-arid tropical climate. Archives of Agronomy and Soil Science, 54:4, 395-400.

Nair, E. V. G., Chinnamma, N. P. Kumari P. K. (1979). A quarter century of research on lemongrass at LRS. Indian Perfum. 23: 218-219.

Prakasha Rao, E. V. S., Narayana M. R., Munnu Singh and Puttanna. (1983). Effect of $\mathrm{N}, \mathrm{P}$ and $\mathrm{K}$ fertilizer on growth yield and nutrient uptake in Java citronella (Cymbopogon winterianus Jowitt). Z. Ackerp Flazerb. 152: 279293.

Prakasa Rao EVS, Singh M, Ganesha Rao RS, Rajeswara Rao BR. 1985. Effect of plant spacing and application of nitrogen fertilizer on herb and essential oil yields of palmarosa (Cymbopogon martinii Stapf.var.motia). J Agric Sci Camb. 104:67-70.

Prakasa Rao EVS, Ganesha Rao RS. 1996. Potassium uptake by some important aromatic crops. J Potassium Res. 12:406-411.

Prakasa Rao EVS, Ganesha Rao RS, Ramesh S. 1996. Changes in content and composition of some essential oils due to possible deficiencies of phosphorus and potassium in a red soil region of Bangalore. Pafai J. 18:25-27.

Prakasa Rao EVS, Ganesha Rao RS, Pattanna K. 2001. Studies on in situ soil moisture conservation and addition of phosphorus and potassium in rain fed palmarosa (Cymbopogon Martiniivar. Motia) in a semi-arid tropical region of India. Eur J Agron. 14:167-172.
Rajeswara Rao BR, Prakasa Rao EVS, Singh K, Singh M, Kaul PN, Bhattacharya AK. 1991. Fertilizer effect on palmarosa (Cymbopogon martinii) under semi-arid tropical conditions of India. Indian J Agric Sci. 61(7):499501.

Rajeswara Rao, B.R., 1999. Aromatic plants for dry areas. In:Singh, R.P., Osman, M. (Eds.), Sustainable Alternate Land Use Systems for Drylands. Oriental Enterprises, Dehradun,India,pp.157170.

Rajeswara Rao, B.R (2001). Biomass and essential oil yields of rainfed palmaros (Cymbopogonmartinii Roxb.) Wats. var. motia Burk.) supplied with different levels of organic manure and fertilizer nitrogen in semi-arid tropical climate. Industrial Crops and Products.14:171178.

Singh M, Sharma S. 2001. Influence of irrigation and nitrogen on herbage and oil yield of Palmarosa (Cymbopogon martinii) under semi-arid tropical conditions. Eur J Agron. 14:157-159.

Singh M, Ganesha Rao RS. 2005. Effects of nitrogen, potassium and soil moisture regime on growth, herbage, oil yield and nutrient uptake of South American marigold (Tagetes minuta L.) in a semiarid tropical climate. J Hort Sci Biotech. 80:488-492.

Singh M, Ganesha Rao RS, Ramesh S. 2005. Effects of nitrogen, phosphorus and potassium on herbage, oil yield, oil quality and soil fertility of lemongrass in a semi-arid tropical region of India. $\mathbf{J}$ Hort Sci Biotech. 80:493-497.

Singh M, Ganesha Rao RS, Ramesh S. 2007. Effects of $\mathrm{N}$ and $\mathrm{K}$ on growth, herbage, oil yield and nutrient uptake pattern of rosemary (Rosmarinus officinalis L.) under semi-arid tropical conditions. J Hort Sci Biotech. 82:414-419.

Somida E. G., 2002. Effect of organic manure 
nitrogen and potassium fertilization on growth, flowering and chemical constituents of marigold plants (Tagetes minuta L.). M. Sci. Thesis of Agric., Cairo Univ., pp 156.

Sundaravadivel, K., T. Chitdeswari, M. Periswamy, M. Subrahamanian and D. Krishnadas. 2000. Nitrogen levels and sources on herb oil yield and soil fertility of rainfed Palmarosa. Madras Agric. J. 86(4-6): 272-274.
Yadav, R. L., M. Anwar and M. Ram. (1984). Fertilizers nitrogen recovery and growth of java citronella as influenced by row spacing and nitrogen. Indian J. Agron. 29:305-308.

Yadav RL, Mohan R, Anwar M, Ram M, Singh DV. 1985. Nitrogen recovery, essential oil yield and quality of palmarosa under different crop geometry and nitrogen rates. Indian $\mathbf{J}$ Agron. 30:23-32.

\section{How to cite this article:}

Cheena, J., V. Krishna Veni, M. Padma and Sreenivas, M. 2020. Studies on the Effect of Nitrogen and Potassium Fertilizers on Growth, Herbage and Oil Yield of Palmarosa in Irrigation Condition (Cymbopogan martini [Roxb.] Will. Watson). Int.J.Curr.Microbiol.App.Sci. 9(12): 3538-3544. doi: https://doi.org/10.20546/ijcmas.2020.912.420 